\title{
Executives vs. governance: Who has the predictive power? Evidence from narrative tone
}

\author{
Hesham Bassyouny ${ }^{1,2}$ (D) Tarek Abdelfattah ${ }^{3,4}$
}

Accepted: 11 June 2021 / Published online: 18 June 2021

(c) The Author(s) 2021

\begin{abstract}
This study aims to investigate not only Narrative Disclosure Tone predictive power, but also who has this power within companies to predict future performance in the UK context (executive vs. governance). We conduct a computerized textual analysis to measure the tone of UK annual reports narratives. Our results contribute to accounting and financial reporting literature by showing that corporate narrative tone can predict future performance. However, answering our main question about who has this predictive power, we found executives' reporting tone has the power to predict a company's future performance but not governance tone. Considering the moderation effect of the 2014 financial reporting guidance, we found this guidance increases corporate narrative tone power in general and executive tone in particular in predicting future performance. Moreover, the current study contributes to financial reporting literature by providing a UK evidence, which operates under the principles-based approach with more flexibility in financial reporting than the US context that follows the rules-based approach. Finally, this study has practical implications for regulators and external users of financial reporting.
\end{abstract}

Keywords Narrative reporting - Tone predictive power - Textual analysis - Executives · Governance

JEL Classification G34 · G40 · M48

Hesham Bassyouny

hesham.bassyouny@northampton.ac.uk

Tarek Abdelfattah

tarek.abdelfattah@port.ac.uk

1 University of Northampton, Waterside Campus, NN4 8GB Northampton, UK

2 Alexandria University, Alexandria, Egypt

3 University of Portsmouth, Portland St, Portsmouth PO1 3DE, UK

4 Mansoura University, Mansoura, Egypt 


\section{Introduction}

Narratives provide credible information alongside financial statements that can affect firms' outcomes (e.g., Merkley 2014; Yekini et al. 2016; Loughran and McDonald 2016). Prior studies in accounting and financial reporting literature have investigated narrative disclosures in different ways as follows, risk reporting (e.g., Linsley and Shrives 2006; Elshandidy, Fraser and Husssainey 2015; Hussein et al. 2020), ForwardLooking disclosure (e.g., Hassanein et al. 2019; Hussainey et al. 2003) and Corporate Social Responsibility (CSR) (e.g., Gray et al. 1995; Dhaliwal, Li, Tsang and Yang 2011). However, it is substantial to investigate how this information is being framed to stakeholders (Blankespoor 2018; Henry and Leone 2016; Pennebaker et al. 2003). As previous studies show that the way of presenting such information affects firms' outcomes and market reaction (e.g Henry and Leone 2016; Brochet et al. 2019). This drives us to explore Narrative Disclosure Tone (NDT) and how managers use language to present information to external users. Tone refers to the optimistic (pessimistic) language used by managers in narrative reporting to convey material information about the company (Henry 2008).

Most of NDT studies investigated the short-term effect of tone on stock market using event study approach and found positive market reaction to optimistic tone (e.g., Price et al. 2012; Feldman et al. 2010; Rahman 2019; Davis and Tama-Sweet 2012; Barakat et al. 2019). However, studies about tone predictive power and its long-term effects are limited (Wisniewski and Yekini 2015; Marquez-Illescas, Zebedee and Zhou 2019). Subsequently, in the current study we are focusing on tone predictive power and its ability to expect companies' future performance in the UK context.

It is worth mentioning that our study aims to examine not only narrative tone predictive power, but also, who has this predictive power inside the company (executives or governance). No one can expect both groups to have the same tone consistency and the same effects on firms' outcomes, as both have a different narrative reporting nature with different responsibilities to report. Executives are responsible for providing a fair view about operational performance, financial reviews and future strategies that might affect future performance. Whereas, governance is responsible for monitoring the internal quality controls, risk management and firms' going concern, which might affect future performance (Melloni, Stacchezzini and Lai, 2016). Therefore, we aim to investigate who has the power to expect future performance (executives vs. governance). Moreover, the UK context is different from the US context, where most tone studies were conducted. The UK context has more flexibility in financial reporting as it follows principle-based approach which might give more opportunities for tone management. However, the US context follows the rule-based approach that has more restrictions in narrative reporting.

We use Loughran and McDonald (2011) wordlist in the textual analysis to measure the tone of narrative reporting in the UK annual reports, after excluding the notes of financial statements and external audit reports. Our sample ended by having 2,322 observations from 2010 to 2019. Loughran and McDonald (2011) wordlist was chosen because it is more applicable in financial reporting and business communications research as it was extracted from financial documents (Bassyouny et al. 2020). In addition, it is more comprehensive compared with other financial based wordlists (Loughran and McDonald 2016). Choosing this examination period allows us to investigate the moderation effect of Financial Reporting Council (FRC) narrative guidance issued in 
2014 and if it improves narrative tone power in predicting future performance. Moreover, we chose annual reports as a channel of narrative disclosure, because it is the largest narrative sample that can represent a company's narrative reporting style (Wisniewski and Yekini 2015).

Our results show that corporate narrative tone can predict future performance, as we found a positive and significant association between net optimistic tone and future ROA. However, investigating the debate about who got this predictive power, we found executive's net optimistic tone is positively and significantly associated with future performance, however governance's tone cannot predict future performance. Therefore, we conclude that executive's tone has the power to predict a company's future performance but not governance's tone. Considering the moderation effect of FRC narratives guidance, we found the narratives guidance issued in 2014 increases corporate narrative tone's power in general and executives' tone in particular in predicting future performance. We report these results after finding narrative tone differs among executives and governance sections. Our results are robust by using an alternative proxy for future performance and abnormal optimistic tone.

This study contributes to accounting and financial reporting literature as follows. First, it contributes to the debate on who has the power to predict future performance inside the company (executives vs. governance). Second, to the best of our knowledge, our study is the first to provide evidence about how narrative linguistic features, named as tone, can predict companies' future performance in the UK that follows a principles-based approach with more flexibility in financial reporting style than the US context. Third, it sheds light on the moderation effect of FRC narrative guidance in improving tone's power to predict future performance. Our study has practical implications by showing investors and analysts the part of annual reports that might predict future performance and providing evidence about the importance of narratives guidance issued by regulators.

Section 2 discusses previous NDT studies and hypotheses development. Second 3 presents the methodology, variables definitions and the empirical model. While Sect. 4 focuses on sample selection and data description. While, Sect. 5 shows the main results of the current research, robustness tests and additional analyses. Finally, Sect. 6 presents the conclusion and the limitations of our research.

\section{Literature review and hypotheses development}

\subsection{The importance of narratives}

In the last decade, textual analysis received more attention in accounting and financial reporting literature (Loughran and Mcdonald 2016; Ataullah et al. 2018). In particular, researchers aim to investigate firms' communication strategies and their impact on investors and financial outcomes (Blankespoor 2018). One of the main channels of communication between the company and external uses is narrative disclosure as part of corporate financial reporting (Schleicher and Walker 2010). Previous research proved that narratives provide credible information alongside financial statements that can affect market reactions and firms' outcomes (e.g., Merkley 2014; Huang et al. 2014; Henry 2008; Davis and TamaSweet 2012; Yekini et al. 2016). They argue that narratives can discuss several aspects, which cannot be covered in financial statements such as firms' strategies, future plans and environmental practices. Moreover, narratives can solve the lack of financial background 
for some investors as they explain beyond financial statements in a simple way (ArslanAyaydin et al. 2016). In addition, over $70 \%$ of financial reporting documents now are narrative disclosures which means researchers should give more attention to these textual disclosures and how they affect firms' outcomes (Li 2010).

\subsection{Prior studies in narrative tone}

Nowadays, researchers in accounting and financial reporting literature argue that it is substantial to know, not only the information content of financial reporting, but also how this information is being framed to stakeholders (Bassyouny et al. 2020; Henry and Leone 2016). As a result, previous research investigated the effect of narrative tone, as one of the important characteristics of narratives, on firms' outcomes. Prior studies investigated the effect of narrative tone among different channels as following press releases (e.g., Henry 2008; Davis et al. 2012; Davis and Tama-Sweet 2012; Kimbrough and Wang 2013; Huang et al. 2014;), social media and online reportage (e.g., Tetlock 2007; Tetlock et al. 2008; Sprengers et al. 2014; Bartov et al. 2018; Bhardwaj and Imam 2019), conference calls (e.g., Davis et al. 2015; Price et al. 2012), and annual reports (e.g., Kothari et al. 2009; Loughran and McDonald 2011 and Yekini et al. 2016).

The great majority of prior studies, which examine the consequences of narrative tone, focus on short-term effects, however, studies about the long-term effects are limited (Wisniewski and Yekini 2015). Most of these studies conducted a short window event study, a few days before and after the event, to examine market reaction to narrative tone in such a context. They expected and found that firms display more positive tone than negative to make investors think about the positive side of the company's performance, therefore, investors react positively in stock markets (e.g., Price et al. 2012; Henry 2008; Feldman et al. 2010; Loughran and McDonald 2011; DeHaan et al. 2015; Henry and Leone 2016; Brochet et al. 2019; Rahman 2019; Barakat et al. 2019; Gordon et al. 2013). Similar to previous research, Davis and Tama-Sweet (2012) found a positive market reaction, using cumulative abnormal return, to net optimistic tone in press releases and MD\&A immediately the day after the issuing date. However, they reported that companies disclose a more optimistic tone in quarter press releases compared with the MD\&A section in 10-Ks, because press releases are more timely documents that get more attention from investors.

In contrast, Huang et al., (2014) conducted three different event studies to investigate the immediate and the long-term market reaction to narrative tone. They noticed investors react positively to positive tone immediately after the press releases are published, but they react negatively in the long term (120 days). These results mean companies sometimes play games with investors and present some bad news in a positive way to let investors react positively for short-term purposes. Similarly, Schleicher and Walker (2010) argue that firms manipulate the tone in order to mislead investors, as they found declining performance companies bias the tone upwards to give investors a good impression about firm performance.

In a different way, Borochin et al., (2018) found that a higher positive tone in conference calls is beneficial as it decreases market uncertainty in the US context. However, Baginski et al., (2018) found a more positive tone leads to more disagreement, measured by trade volume between investors. Nevertheless, in their additional analysis, they have similar results with Tan, Wang and Zhou (2014) as they found small investors are more likely to be misled by an optimistic tone than sophisticated investors. 


\subsection{Hypotheses development}

\subsubsection{Executives vs. governance narrative reporting}

This study aims to investigate not only tone predictive power for future performance, but also who has this power inside the company (executives or governance). Therefore, in this section, we explore and discuss the narrative reporting features for both executives and governance sections. It is noticeable that executives and governance teams are the strongest two groups within the company in general and are included in the narrative reporting process in particular, as these sections represent over $70 \%$ of annual reports narratives ( $\mathrm{Li}$ 2010). However, no one can expect that these two groups with different responsibilities would have the same tone in their narrative reporting and the same effects on firms' outcomes. On one hand, executives provide information about current and future performance, financial position, operational and financial review and future developments and strategies (Clatworthy and Jones 2003; Davis et al. 2015). Executives report this information in order to give a fair review for the company's' future and provide material information for investors and external users (Yekini et al. 2016; Marquez-Illescas et al. 2019).

On the other hand, governance team in general and audit committee in particular are responsible for monitoring the effectiveness of internal quality control, risk management system, corporate going concern and monitoring the financial reporting process (Zalata et al. 2018). According to the previous discussion, and how different the responsibilities are for both groups, consequently, their narrative reporting style, we argue that both groups have different tone consistency in UK annual reports narratives.

H1: Net optimistic tone differs in UK annual reports narratives among executives and governance sections.

\subsubsection{Tone predictive power}

Most NDT studies focus on short-term market reactions as tone consequences (e.g., Davis et al. 2012; Yekini et al. 2016). However, narratives contain useful information discussing firm's future visions, strategies and operations which might affect future performance for the long-term (Bryan 1997). Therefore, our main focus for the current study is to investigate the tone predictive power by examining if narrative tone can predict future performance for the subsequent years.

Few studies have examined the long-term consequences of narrative reporting. Wisniewski and Yekini (2015) found that UK narrative characteristics, named as Activity and Realism, can predict future abnormal returns using a long window event study (1, 250), whereas Bryan (1997) found MD\&A disclosure level, especially the discussion of future operations is associated with the next quarter performance. Our study is different from these previous studies. While they focused on the characteristics of narratives in general and the amount of disclosures in narrative reports, we focus on the presenting method and how managers frame information to external users, not the content of information, to investigate if the tone of these narratives can predict future performance.

Moreover, few studies have investigated narrative tone predictive power and they found optimistic tone is associated with higher future ROA in the subsequent quarter (Davis et al. 2015; Patteli and Pedrini 2014; Boudt et al. 2018; Druz et al. 2020). Whereas, D'Augusta and DeAngelis (2020) confirm these findings and add that the 
relationship between tone and earning performance depends of whether the company meets or beats investors' expectations. In addition, previous studies link NDT with social performance and found optimistic tone is associated with future CSR performance (Du and Yu 2020). However, our study adds to previous studies in different ways as follows. First, the current study aims to report about not only narrative tone predictive power, but also, who has this predictive power inside the company, is it the executives or governance. This might have an implication to investors and analysts providing them with the part of annual reports narratives that can expect company's future performance. Second, prior studies in this area examined US data, whereas we are investigating the UK context, which has different regulatory settings. The UK follows a principles-based approach that provides more flexibility in financial reporting than the US context that follows rules-based approach (Bassyouny et al. 2020; Yekini et al. 2016). Third, it aims to investigate the effect of 2014 FRC narrative guidance in monitoring tone predictive power and its ability to expect future performance. Fourth, previous studies focused on accounting-based performance as a proxy of future performance; however, in the current study we consider both accounting and market-based performance to investigate future performance.

In addition, prior studies suggest that firms with good performance disclose this information positively to send signals to the external users, and both current and potential investors about their performance to differentiate themselves from companies with poor performance (Clatworthy and Jones 2003; Spence 1973). Therefore, they will have a more optimistic tone in their narratives trying to describe the current performance and giving good indicators for future performance and a company's position in stock markets (Smith and Taffler 2000). According to the previous discussion, the current study expects narrative tone to predict future performance.

H2: There is a significant positive association between net optimistic tone in UK annual reports narratives and future performance.

As mentioned above, we aim to report about not only narrative tone predictive power, but also who has this predictive power (executives or governance). Executives are responsible for providing external users with a fair review about firm performance and future plans. Moreover, they aim to maximize their benefits by focusing on good news and presenting information in a positive way to satisfy current investors and attract potential investors (Patteli and Pedrini 2014; Davis et al. 2012; Yekini et al. 2016; Bartov et al. 2018; Clatworthy and Jones 2006; DeBoskey et al. 2019). Therefore, we argue that executives' tone might expect company's future performance. Whereas governance teams are responsible for monitoring the financial reporting process and reporting about firm responsibilities, principle risks and going concern which affects firms' outcomes (Melloni et al. 2016; Mangena and Pike 2005). We argue that, as long as governance teams are responsible to report about principle risks and firms' going concern, these reports can be related to expecting future performance. Therefore, we aim to investigate which group's tone has the predictive power and can expect firm future performance.

H2a: There is a significant positive association between executive's net optimistic tone in UK annual reports narratives and future performance.

H2b: There is a significant positive association between governance's net optimistic tone in UK annual reports narratives and future performance. 


\subsection{The research context}

We argue that the UK is a unique context to investigate narrative tone for two reasons. First, the UK regulatory setting is different from the US context, where most of the NDT studies have been conducted. The UK follows a principle-based approach, which has more flexibility in narrative reporting and allows managers to be more inclined in framing the tone of narrative reporting, compared with the US, which follows a rule-based approach with more restrictions in narrative reporting style (Yekini et al. 2016). Second, the UK regulation settings received more attention about narrative reporting recently from FRC by issuing the guidance for strategic reporting in 2014, which aims to improve the UK narrative reporting and encourages companies to disclose information related to long-term performance (FRC 2014).

\section{Methodology}

\subsection{Tone measurement}

This study aims to examine narrative tone predictive power and if tone can predict future performance in the UK context. Therefore, we conduct a computerized textual analysis and employ the bag-of-words approach by using a software called CFIE in order to measure the tone of narrative reporting. This approach is commonly used in financial reporting research and in NDT research in particular. It aims to calculate the frequency of positive and negative words in the financial documents in order to capture the tone of narrative reporting (Bassyouny et al. 2020; Henry and Leone 2016).

Following previous studies in NDT (e.g., Feldman et al. 2010; Davis and Tama-Sweet 2012; Marquez-Illescas et al. 2019; Huang et al. 2014; Lee and Park 2019), we chose Loughran and McDonald (2011) wordlist to measure NDT. The reasons behind that are, first, it is generated based on a financial document,10-K filings, consequently it is more applicable in financial reporting studies than other general dictionaries (Bassyouny et al. 2020). Second, it is more comprehensive compared with Henry (2008) wordlist. As a result, net optimistic tone is calculated as (Positive-Negative) words divided by the total number of words to control for the length of the annual reports (Feldman et al. 2010; Davis et al. 2015; Loughran and McDonald 2011; Davis and Tama-Sweet 2012; Arslan-Ayaydin et al. 2016).

Since our objective is to investigate not only tone predictive power, but also to find out who has this power, executives vs. governance, to predict future performance. We have three proxies of net optimistic tone. First, corporate Net Optimistic Tone, which covers the tone of entire annual report narratives to examine if narrative tone is able to predict future performance. Then, in order to examine who has the predictive power we extracted executive sections and governance sections to measure the net optimistic tone for both groups. Therefore, the second is Executives Net Optimistic Tone, which focuses on executives' reporting (Chairman Statements, CEO letters to shareholders, Operational and Financial review written by CEO and CFO of the company). The third is Governance Net Optimistic Tone, which focuses on governance reports, including audit committee reports.

This study focuses on the UK corporate annual reports narratives that represents the company's narrative reporting style, therefore we excluded the external auditor reports 
Table 1 Variables definition

\begin{tabular}{|c|c|}
\hline Variable & Definition \\
\hline Net_Tone & $\begin{array}{l}\text { Number of (positive words-negative words) divided by the total number of words in } \\
\text { annual report }\end{array}$ \\
\hline Exec_Net_Tone & $\begin{array}{l}\text { Number of (positive words-negative words) in the executives' section divided by the } \\
\text { total number of words of that section }\end{array}$ \\
\hline Gov_Net_Tone & $\begin{array}{l}\text { Number of (positive words-negative words) in the governance's section divided by } \\
\text { the total number of words of the section }\end{array}$ \\
\hline $\mathrm{ROA}+1$ & Proxy of future performance, using future return on assets for the subsequent year \\
\hline $\mathrm{ROE}+1$ & Alternative measure for future performance, return on Equity (ROE) ratio \\
\hline Firm Size & Natural logarithm of total assets at the end of fiscal year \\
\hline Leverage & Total liabilities over total assets \\
\hline MTB & Market price to book value ratio \\
\hline Dividend & dividend per share \\
\hline ROA & Return on assets, as an indicator for current performance \\
\hline Sales growth & Change in sales compared with the previous fiscal year \\
\hline FRC & Dummy variable $=1$ for years after 2014, and equal 0 otherwise \\
\hline Board Independence & Percentage of independent directors in the board \\
\hline Board Diversity & Percentage of females on board of directors per year \\
\hline AC_Size & Number of members on the board of directors \\
\hline AC_IND & Percentage of independent members in the audit committee \\
\hline AC_Activity & Number of audit committee meetings per year \\
\hline CEO_Comp & Natural log for total salaries and bonuses that the CEO gets from the company \\
\hline
\end{tabular}

section and the notes of financial statements. We chose CFIE software to conduct textual analysis as CFIE is designed for the UK annual reports PDF structure and it transfers the PDF to text and separates the entire annual report to different sections based on the table of contents in the PDF file (El-Haj et al., 2020). After that, it gives the results of word frequencies for the whole annual report and the separated sections as well, therefore, it is suitable for the current study since we are examining the whole annual report plus focusing on specific sections. Moreover, it is important to mention that UK listed companies are required to release their annual reports at the latest four months after the end of the fiscal year, therefore we link the tone of annual reports with the performance of the subsequent year to investigate tone predictive power. Finally, other firm financial characteristics variables to measure future performance and control variables are defined in Table 1.

\subsection{Empirical models}

We investigate tone predictive power in UK context by applying the following regression model:

$$
\begin{aligned}
R O A+1_{i t+1}= & \propto+\beta_{1} \text { Net_Tone }_{i t}+\beta_{2} \text { Size }_{i t}+\beta_{3} \text { Leverage }_{i t}+\beta_{4} \text { MTB }_{i t}+\beta_{5} D I V_{i t} \\
& +\beta_{6} \text { ROA }_{i t}+\beta_{7} S_{-} \text {Growth }_{i t}+\text { Year_FE }_{t}+\text { Firm_FE }_{t}+I N D \_F E_{i}+\varepsilon_{i t}
\end{aligned}
$$

$R O A+1$ is a proxy for future performance measured as ROA for the subsequent fiscal year (Davis et al. 2015; Patteli and Pedrini 2014). Whereas Net_Tone is equal 
(positive-negative) words divided by the total number of words in order to control for the length of the annual reports (e.g., Bassyouny et al. 2020; Davis and Tama-Sweet 2012; Arslan-Ayaydin et al. 2016; Yekini et al. 2016). This model controls for firm characteristics that might affect firms' outcomes as follows. Previous studies suggest controlling for Firm_Size because big companies have more conservatism strategies and disclose more balanced information to avoid future risks (Rogers et al. 2011). Moreover, we control for credit crunch using leverage ratio (Yekini et al. 2016). In addition, we control for Sales_ growth, ROA, Dividend and MTB, as an indicator for growth, current performance, investment activities and market risk respectively (Bassyouny et al. 2020). Moreover, we include firm-fixed effect in order to control for firm time invariant characteristics and reduce endogeneity issues.

To investigate who has the power inside the company to predict future performance, we run the same model but using Executives_Net_Tone and Governance_Net_Tone, instead of Net_Tone, respectively in model (2) and (3).

$$
\begin{aligned}
R O A+1_{i t+1}= & \propto+\beta_{1} \text { Exec_Net_Tone }_{i t}+\beta_{2} \text { Size }_{i t}+\beta_{3} \text { Leverage }_{i t}+\beta_{4} M T B_{i t}+\beta_{5} D I V_{i t} \\
& +\beta_{6} \text { ROA }_{i t}+\beta_{7} S_{-} \text {Growth }_{i t}+\text { Year_FE }_{t}+\text { Firm_FE }_{t}+I N D_{-} F E_{i}+\varepsilon_{i t} \\
\text { ROA }+1_{i t+1}= & \propto+\beta_{1} \text { Gov_Net_Tone }_{i t}+\beta_{2} \text { Size }_{i t}+\beta_{3} \text { Leverage }_{i t}+\beta_{4} M T B_{i t}+\beta_{5} D I V_{i t} \\
& +\beta_{6} \text { ROA }_{i t}+\beta_{7} S_{-} \text {Growth }_{i t}+\text { Year_FE }_{t}+\text { Firm_FE }_{t}+I N D_{-} F E_{i}+\varepsilon_{i t}
\end{aligned}
$$

where Exec_Net_Tone equal (positive-negative) words in the executive section divided by the total number of words for the section. Whereas, Gov_Net_Tone equal (positive-negative) words in the governance section divided by the total number of words for the section. We use the same control variables that were used in model (1) as explained above.

\section{Data}

Our sample is based on FTSE All-Share Index. However, we excluded 283 firms from the financial services sector because of having different accounting practices and financial statements structure (Schleicher and Walker 2010). In addition, we excluded 36 firms with missing data and companies that their annual reports were available as pictures and it was not possible to transfer them to text for the textual analysis process. Our final sample consists of 224 UK listed companies from 2010 to 2019. Our sample starts from 2010 to avoid the noises during the financial reporting crisis.

In addition, investigating NDT in this period will allow us to cover UK narrative reporting around the 2014 FRC narrative reporting guidance. As we aim to report about the FRC moderation effect on the relationship between NDT and future performance in order to know whether this regulatory guidance has an effect or not. We collected the annual reports for our sample from Bloomberg database and firms' websites, that was reflected in having 2,322 firm observations.

While prior tone studies investigated different channels of narrative reporting, we are focusing on annual reports rather than other channels of financial reporting for two reasons. First, annual reports provide a larger sample of narratives that can represent the narrative reporting style for the company (Wisniewski and Yekini 2015; Loughran and Mcdonald 2016). Second, analyzing annual reports narratives enables us to provide information about 
Table 2 Descriptive statistics

\begin{tabular}{lcccll}
\hline Variable & Obs & Mean & Std.Dev & Min & Max \\
\hline Net_Tone & 2,322 & 0.0021 & 0.0051 & -0.0982 & 0.0550 \\
Exec_Net_Tone & 2,322 & 0.1428 & 0.0052 & 0.0425 & 0.1957 \\
Gov_Net_Tone & 2,322 & 0.0471 & 0.0053 & -0.0595 & 0.0862 \\
ROA+1 & 2,322 & 6.2965 & 14.9052 & -68.9512 & 236.7815 \\
Size & 2,322 & 7.2090 & 1.7007 & 2.3228 & 12.9270 \\
Lev & 2,322 & 21.7787 & 18.3461 & 0 & 165.5771 \\
MTB & 2,322 & 4.2415 & 37.8824 & -964.2491 & 918.2393 \\
DIV & 2,322 & 0.2186 & 0.3419 & 0 & 3.07 \\
ROA & 2,322 & 6.2966 & 92.9912 & -345.5713 & 240.862 \\
S_Growth & 2,322 & 8.246 & 22.416 & -93.44 & 383.89 \\
ROE+1 & 2,322 & 24.89 & 82.99 & -254.86 & 209.256 \\
ROA+2 & 2,321 & 6.897 & 15.379 & -69.129 & 278.145 \\
B_IND & 2,206 & 60.884 & 12.984 & 0 & 92.86 \\
B_Diversity & 2,206 & 15.583 & 11.032 & 0 & 57.14 \\
AC_Size & 2,206 & 3.623 & 0.9165 & 2 & 8 \\
AC_IND & 2,206 & 97.983 & 8.674 & 0 & 100 \\
AC_Activity & 2,206 & 4.223 & 1.488 & 0 & 15 \\
CEO_Comp & 2,206 & 14.196 & 0.841 & 9.876 & 18.069 \\
\hline
\end{tabular}

tone consistency in annual reports narratives and compare between the tone of executives and governance sections to examine who has the tone predictive power.

Finally, in order to examine tone predictive power and its effect on future performance, we collect data about firm performance $(\mathrm{ROA}+1)$ and other firm financial characteristic data from the Bloomberg database. In addition, more control variables were collected from Bloomberg as mentioned in the variables definition in Table 1.

\section{Empirical results}

\subsection{Descriptive statistics and correlations}

Table 2 presents the variables' descriptive statistics. The mean value of Net_Tone in our sample is 0.002 , which shows that UK annual reports narratives have a variation between positive and negative words; however, they have more positivity. This value is similar to NDT studies that measure net optimistic tone by calculating (positive-negative) words divided by the total number of words in order to control for the length (e.g., Yekini et al. 2016; Davis and Tama-Sweet 2012; Davis et al. 2015; Marquez-Illescas et al. 2019). It is obvious that the mean value of Exec_Net_Tone and Gov_Net_Tone is different. The mean value of Exec_Net_Tone is 0.1428 indicating that $14.28 \%$ of executive sections in annual reports have optimistic tone. However, the mean value of Gov_Net_Tone is 0.0471 indicating that just $4.71 \%$ of governance sections in annual reports have optimistic tone. Therefore, we conclude that executives have more optimistic tone in annual reports narratives compared with governance reporting, supporting $\mathrm{H} 1$ assuming that net optimistic tone differs among executives and governance sections. 
We argue that these results can be explained by the different responsibilities for both groups as executives are responsible for giving a fair view about companies' performance, and therefore, they want to present the information in a positive way to attract new investors. However, governance team is more responsible for monitoring the financial reporting process, internal control quality, risk management strategies and going concern. Moreover, our descriptive shows that Fut_ROA has an average of 6.29 and the average of firm size in our sample is 7.21 . The mean value of $(D P S)$ is 0.22 , also the mean value of the current performance according to (ROA) is 6.29 .

Table 3 shows the Person correlation matrix, moreover it provides an initial relationship between the explanatory variables and the association with the dependent variable (Fut $R O A$ ); In addition, it shows any potential indicators for multicollinearity. The correlation matrix shows that small companies, firms with higher growth, higher current performance and lower leverage ratio have more optimistic tone and better future performance. These findings are similar to previous NDT studies (e.g., Wisniewski and Yekini 2015). Finally, it is noticeable that the correlation among the explanatory variables is comparatively low, suggesting no multicollinearity problems in our examination.

\subsection{Multivariable results and discussion}

\subsubsection{Corporate narrative tone predictive power}

Table 4 shows the main findings of the OLS regression of the current study. Column (1) reports about corporate narrative tone predictive power of future accounting performance. We found that corporate net optimistic tone in annual reports narratives is positively and significantly associated with future ROA, showing a 0.1548 coefficient and t score of 3.69. Supporting H2, which is assuming that, net optimistic tone in the UK context can predict future performance. This is consistent with prior studies in the US context arguing that narrative tone is positively associated with the subsequent quarter performance (e.g., ArslanAyaydin et al. 2016; Davis et al. 2015). In addition, the high R2 is because of controlling for the current performance for the company, these results are similar to previous literature (e.g., Davis et al. 2012; Li 2010). Moreover, this result supports signalling theory, which assumes that improving performance companies aim to send a good signal about current and future performance to external users to distinguish themselves from companies with bad performance (Smith and Taffler 2000).

In addition, we control for firm characteristics that may impact future performance. We found that small firms and lower leverage ratio companies have better performance for the subsequent year whereas companies with higher growth, current performance and those paying more dividends have better future performance. In order to examine if multicollinearity problem impacts the findings in model (1), we calculate the variance inflation factor (VIF) which is a common way that is used in accounting and finance literature to indicate for multicollinearity if the value is higher than 10 (Chatterjee and Price 1991). The VIF value for model (1) is 4.18; consequently, we report no multicollinearity problem in this model.

\subsubsection{Executives vs. governance tone predictive power}

As mentioned before, the current study aims to report about not only narrative tone predictive power, but also who has this predictive power inside the company, is it the 


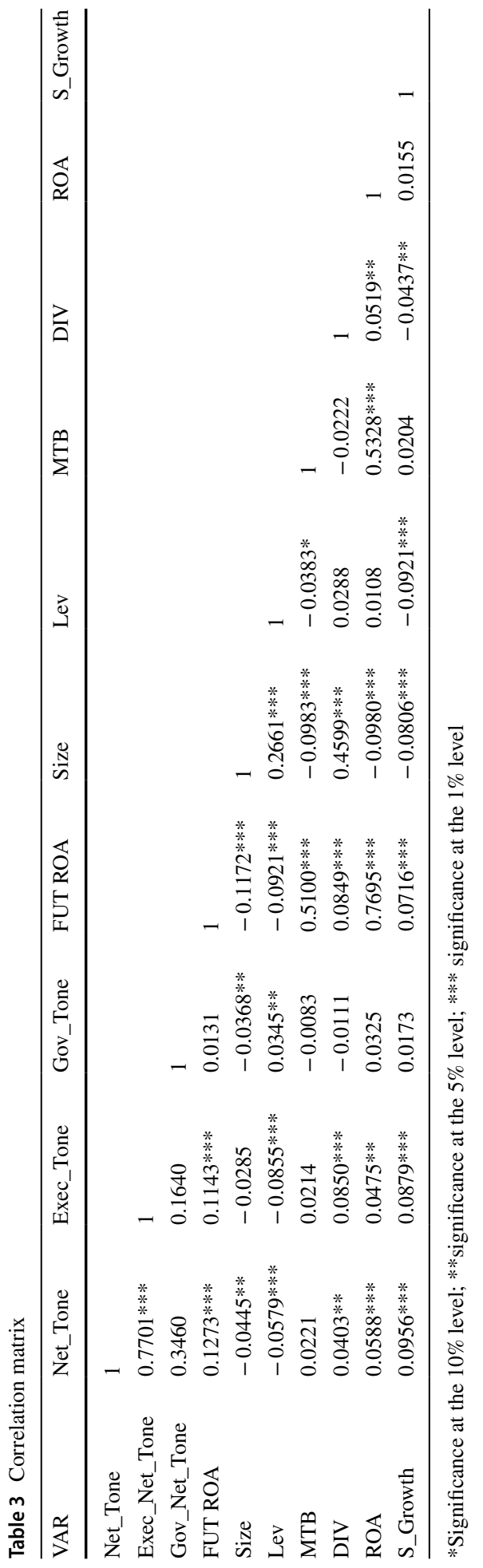


Table 4 Narratives tone predictive power (future performance)

\begin{tabular}{|c|c|c|c|}
\hline $\mathrm{ROA}+1$ & Model (1) & Model (2) & Model (3) \\
\hline Intercept & $\begin{array}{l}3.6613 * * * \\
(3.34)\end{array}$ & $\begin{array}{l}1.1382^{* * *} \\
(1.57)\end{array}$ & $\begin{array}{l}3.2218 * * * \\
(3.73)\end{array}$ \\
\hline Net_Tone & $\begin{array}{l}0.1548 * * * \\
(3.69)\end{array}$ & & \\
\hline Exec_Net_Tone & & $\begin{array}{l}0.1556^{* * * *} \\
(3.74)\end{array}$ & \\
\hline Gov_Net_Tone & & & $\begin{array}{l}0.0417 \\
(0.12)\end{array}$ \\
\hline Size & $\begin{array}{l}-0.6165 * * * \\
(-7.20)\end{array}$ & $\begin{array}{l}-0.6153 * * * \\
(-7.19)\end{array}$ & $\begin{array}{l}-0.5887 * * * \\
(-6.81)\end{array}$ \\
\hline Lev & $\begin{array}{l}-0.0149 * * \\
(-0.76)\end{array}$ & $\begin{array}{l}-0.0152 * * \\
(-0.77)\end{array}$ & $\begin{array}{l}-0.0214^{* *} \\
(-1.09)\end{array}$ \\
\hline MTB & $\begin{array}{l}0.0516^{* * * *} \\
(9.46)\end{array}$ & $\begin{array}{l}0.0513 * * * \\
(9.45)\end{array}$ & $\begin{array}{l}0.0518 * * * \\
(9.47)\end{array}$ \\
\hline DIV & $\begin{array}{l}5.6213 * * * \\
(3.99)\end{array}$ & $\begin{array}{l}5.6188 * * * \\
(3.99)\end{array}$ & $\begin{array}{l}5.9266^{* * * *} \\
(4.20)\end{array}$ \\
\hline ROA & $\begin{array}{l}0.3541 * * * \\
(1.87)\end{array}$ & $\begin{array}{l}0.3568 * * * \\
(1.88)\end{array}$ & $\begin{array}{l}0.3556^{* * * *} \\
(1.87)\end{array}$ \\
\hline S_Grwoth & $\begin{array}{l}0.3351 * * * \\
(5.72)\end{array}$ & $\begin{array}{l}0.3369 * * * \\
(5.75)\end{array}$ & $\begin{array}{l}0.3578 * * * \\
(6.10)\end{array}$ \\
\hline Yea FE & YES & YES & YES \\
\hline Firm FE & YES & YES & YES \\
\hline Industry FE & YES & YES & YES \\
\hline Observations & 2,322 & 2,322 & 2,322 \\
\hline VIF & 4.18 & 4.18 & 4.05 \\
\hline Adj-R2 & $78.60 \%$ & $78.59 \%$ & $78.42 \%$ \\
\hline
\end{tabular}

*Significance at the $10 \%$ level; **significance at the $5 \%$ level; *** significance at the $1 \%$ level. Coefficient for each variable is mentioned, t-test scores are between brackets

executives or governance. Column (2) and (3) in Table 4 report about executives and governance tone predictive power of future performance respectively (model 2 and 3 ). We found that executives' net optimistic tone in annual reports narratives is positively and significantly associated with future ROA, with a coefficient of 0.1556 and t value of 3.74. Supporting H2a that executives' net optimistic tone in UK annual reports narratives can predict future performance. However, we found that governances' net optimistic tone is positively associated with future ROA, with a coefficient of 0.0417 and $t$ value of 0.12 , but it is not significant. Therefore, we reject $\mathrm{H} 2 \mathrm{~b}$ assuming governance net optimistic tone can predict future performance.

As a result, we conclude that executive's tone has the power to predict future performance for the company, but not governances' tone. These results can be explained by the nature of narrative reporting for both of them as they have different responsibilities. Executives provide a fair view about firm performance, operational and financial review, future developments and strategies, which is more related to future performance. However, governance team is responsible for reporting about risk management and monitoring the process of financial reporting. These results support signalling theory that managers have more incentive to send good signals about firm performance to external 
users to satisfy current shareholders and attract potential investors (Clatworthy and Jones 2003).

Moreover, we control for the same firm characteristics that have been used in model (1) and we found the same results that small companies have better performance and current profitability and growth ratio are significantly associated with future performance. The VIF score for model (3) and (4) are 4.18 and 4.05 respectively, and therefore, we conclude there is not multicollinearity problem in these models.

\subsection{Endogeneity checks}

\subsubsection{Omitted variables bias}

In the main analysis for investigating NDT predictive power, we used firm-specific characteristics as control variables. However, this robustness test aims to address the concern of endogeneity due to omitted variables. Therefore, the current study includes CG mechanisms as additional controls that can affect NDT and future performance (Melloni et al. 2016; Li 2010B). Moreover, we take into account audit committee characteristics because audit committee plays an important part in monitoring the financial reporting progress (Wang and Hussainey 2013; Zalata et al. 2018B). Moreover, board characteristics is important to be considered while investigating NDT as it can be one of the effective NDT determinants and it can be related to future performance (Li 2010B; Iatridis 2016). In addition, we include CEO compensation as control variable because it can be argued that since this information is available in the annual report, the tone of narratives may not be as important as the incentive for the CEO to affect future performance. ${ }^{1}$

Table 5 shows the results of the additional controls to examine the association between NDT and future performance. The results remain the same after controlling for CG mechanisms and CEO compensation, as this analysis confirms the main results that NDT is associated with future performance and can expect company's future performance. Moreover, it confirms the main findings that executives' tone, but not governance, is associated with future performance, meaning that it can be used in helping external users in predicting future performance.

\subsubsection{Robustness test (alternative measure for future performance)}

We use an alternative measure for future performance in order to account for endogeneity problems related to measurement errors and as a robustness test of our main findings. While we used future ROA in our main analyses as a proxy of future performance, we use future Return on Equity (ROE) as an alternative proxy to measure future performance. The results in Table 6 support our main results that corporate net optimistic tone is positively and significantly associated with future performance. Moreover, our robustness analyses confirm that executives' net optimistic tone, but not governances' tone, has the power to predict future performance for the company.

${ }^{1}$ We would like to thank the reviewer for the suggestion to include a proxy for CEO compensation. 
Table 5 Omitted variables bias

\begin{tabular}{|c|c|c|c|}
\hline $\mathrm{ROA}+1$ & Model (1) & Model (2) & Model (3) \\
\hline Intercept & $\begin{array}{l}3.1014 * * * \\
(1.20)\end{array}$ & $\begin{array}{l}1.8978 * * \\
(1.89)\end{array}$ & $\begin{array}{l}3.1053^{* * * *} \\
(3.78)\end{array}$ \\
\hline Net_Tone & $\begin{array}{l}0.1456 * * * \\
(3.49)\end{array}$ & & \\
\hline Exec_Net_Tone & & $\begin{array}{l}0.1428 * * * \\
(3.48)\end{array}$ & \\
\hline Gov_Net_Tone & & & $\begin{array}{l}0.0342 \\
(0.10)\end{array}$ \\
\hline B_IND & $\begin{array}{l}0.0566 * * * \\
(2.36)\end{array}$ & $\begin{array}{l}0.0674 * * * \\
(2.12)\end{array}$ & $\begin{array}{l}0.0583 \text { *** } \\
(2.42)\end{array}$ \\
\hline B_Diversity & $\begin{array}{l}0.0169 * * \\
(1.65)\end{array}$ & $\begin{array}{l}0.0164 * * \\
(0.63)\end{array}$ & $\begin{array}{l}0.0149 * * \\
(0.57)\end{array}$ \\
\hline AC_Size & $\begin{array}{l}0.1409 \\
(2.34)\end{array}$ & $\begin{array}{l}0.1364 \\
(0.49)\end{array}$ & $\begin{array}{l}0.1301 \\
(0.47)\end{array}$ \\
\hline AC_IND & $\begin{array}{l}0.0631 * * * \\
(2.34)\end{array}$ & $\begin{array}{l}0.0634 * * * \\
(2.35)\end{array}$ & $\begin{array}{l}0.0637 * * * \\
(2.35)\end{array}$ \\
\hline AC_Activity & $\begin{array}{l}0.4518 * * \\
(2.32)\end{array}$ & $\begin{array}{l}0.4493 * * \\
(2.31)\end{array}$ & $\begin{array}{l}0.4827 * * \\
(2.47)\end{array}$ \\
\hline CEO_Comp & $\begin{array}{l}0.1897 * * * \\
(2.58)\end{array}$ & $\begin{array}{l}0.1891 \text { *** } \\
(2.57)\end{array}$ & $\begin{array}{l}0.1951 \text { *** } \\
(2.65)\end{array}$ \\
\hline Other controls & YES & YES & YES \\
\hline Year FE & YES & YES & YES \\
\hline Firm FE & YES & YES & YES \\
\hline Industry FE & YES & YES & YES \\
\hline Observations & 2,206 & 2,206 & 2,206 \\
\hline VIF & 3.30 & 3.30 & 2.03 \\
\hline Adj-R2 & $78.76 \%$ & $78.75 \%$ & $78.63 \%$ \\
\hline
\end{tabular}

*Significance at the $10 \%$ level; **significance at the $5 \%$ level; *** significance at the $1 \%$ level. Coefficient for each variable is mentioned, t-test scores are between brackets

\subsection{Additional analyses}

\subsubsection{Moderating effect of FRC narratives guidance}

Recently, the UK regulation settings received more attention about narrative reporting from FRC by issuing narrative reporting guidance in 2014 aiming to improve narrative reporting quality. Therefore, in our additional analysis we aim to investigate the moderation effect of the guidance issued by FRC on the relationship between narrative tone and future performance. Consequently, we can report if this guidance helps narrative tone in predicting future performance and providing external users with relevant useful information. In order to investigate the FRC narratives guidance moderation effect, we use the following regression model: 
Table 6 Robustness analysis (Alternative measure for Future performance)

\begin{tabular}{|c|c|c|c|}
\hline $\mathrm{ROE}+1$ & Model (1) & Model (2) & Model (3) \\
\hline Intercept & $\begin{array}{l}1.4635^{*} \\
(0.50)\end{array}$ & $\begin{array}{l}1.5037 * * \\
(3.10)\end{array}$ & $\begin{array}{l}1.3376^{*} \\
(0.42)\end{array}$ \\
\hline Net_Tone & $\begin{array}{l}0.1198 * * * \\
(3.32)\end{array}$ & & \\
\hline Exec_Net_Tone & & $\begin{array}{l}0.1169 * * * \\
(3.28)\end{array}$ & \\
\hline Gov_Net_Tone & & & $\begin{array}{l}0.1929 \\
(0.08)\end{array}$ \\
\hline Size & $\begin{array}{l}-3.4661 * * \\
(-0.84)\end{array}$ & $\begin{array}{l}-3.3415^{* *} \\
(-0.81)\end{array}$ & $\begin{array}{l}-1.6657 * * \\
(-0.40)\end{array}$ \\
\hline Lev & $\begin{array}{l}-0.1961 \\
(-1.51)\end{array}$ & $\begin{array}{l}-0.1989 \\
(-1.53)\end{array}$ & $\begin{array}{l}-0.2432^{*} \\
(-1.87)\end{array}$ \\
\hline MTB & $\begin{array}{l}0.6625 * * * \\
(9.75)\end{array}$ & $\begin{array}{l}0.6623 * * * \\
(9.74)\end{array}$ & $\begin{array}{l}0.6643 * * * \\
(9.71)\end{array}$ \\
\hline DIV & $\begin{array}{l}8.5979 * * \\
(1.42)\end{array}$ & $\begin{array}{l}9.6486^{* * *} \\
(1.43)\end{array}$ & $\begin{array}{l}8.0012 * * \\
(1.69)\end{array}$ \\
\hline ROA & $\begin{array}{l}0.3553 * * * \\
(2.87)\end{array}$ & $\begin{array}{l}0.3573 * * * \\
(2.89)\end{array}$ & $\begin{array}{l}0.3522 * * * \\
(2.83)\end{array}$ \\
\hline S_Grwoth & $\begin{array}{l}0.0501 \\
(1.25)\end{array}$ & $\begin{array}{l}0.0515 \\
(1.29)\end{array}$ & $\begin{array}{l}0.0679 * \\
(1.69)\end{array}$ \\
\hline Year FE & YES & YES & YES \\
\hline Firm FE & YES & YES & YES \\
\hline Industry FE & YES & YES & YES \\
\hline Observations & 2,322 & 2,322 & 2,322 \\
\hline VIF & 4.16 & 4.16 & 3.02 \\
\hline Adj-R2 & $73.91 \%$ & $73.90 \%$ & $73.66 \%$ \\
\hline
\end{tabular}

*Significance at the $10 \%$ level; **significance at the $5 \%$ level; *** significance at the $1 \%$ level. Coefficient for each variable is mentioned, t-test scores are between brackets

$$
\begin{aligned}
R O A+1_{i t+1}= & \propto+\beta_{1} \text { Net_Tone }_{i t}+\beta_{2} F R C_{i t}+\beta_{3} \text { Net_Tone } * F R C_{i t}+\beta_{4} \text { Size }_{i t} \\
& +\beta_{5} \text { Leverage }_{i t}+\beta_{6} \text { MTB }_{i t}+\beta_{7} D I V_{i t}+\beta_{8} R O A_{i t}+\beta_{9} S_{-} \text {Growth }_{i t}+\text { Year_FE }_{i} \\
& + \text { Firm_FE }_{i}+I N D \_F E_{i}+\varepsilon_{i t}
\end{aligned}
$$

where $R O A+1$ and Net_Tone is measured following the same in model (1) as a proxy of future performance and net optimistic tone respectively. While FRC is a proxy of regulatory narrative guidance issued by FRC equal 1 if year is $>2014$ and equal 0 otherwise, Net Tone*FRC represents the moderation effect of FRC guidance for the relationship between Net_Tone and future performance.

Column (1) in Table 7 presents moderation effect of FRC guidance on the relationship between Net_Tone and future performance. While Net_Tone remains positively and significantly associated with future performance, with a 0.1395 coefficient and $t$ score of 2.79 , the interaction between Net_Tone and FRC is positively and significantly associated with future performance, with a 0.3357 coefficient and $1.53 \mathrm{t}$ score. These findings show that the new narratives guidance issued by FRC increases corporate narrative tone power in predicting future performance. 
Table 7 FRC moderation effects

\begin{tabular}{|c|c|c|c|}
\hline $\mathrm{ROA}+1$ & Model (1) & Model (2) & Model (3) \\
\hline Intercept & $\begin{array}{l}3.2749 * * * \\
(4.35)\end{array}$ & $\begin{array}{l}1.3616^{* *} \\
(1.65)\end{array}$ & $\begin{array}{l}3.2667 \text { **** } \\
(4.83)\end{array}$ \\
\hline Net_Tone & $\begin{array}{l}0.1395 * * * \\
(2.79)\end{array}$ & & \\
\hline FRC & $\begin{array}{l}-1.7335^{* *} \\
(-2.15)\end{array}$ & $\begin{array}{l}-1.7534^{*} \\
(-0.46)\end{array}$ & $\begin{array}{l}-1.0192 * \\
(-1.46)\end{array}$ \\
\hline Net_Tone*FRC & $\begin{array}{l}0.3357^{*} \\
(1.53)\end{array}$ & & \\
\hline Exec_Net_Tone & & $\begin{array}{l}0.1357 * * * \\
(2.93)\end{array}$ & \\
\hline Exec_Net_Tone*FRC & & $\begin{array}{l}0.1698 * \\
(0.57)\end{array}$ & \\
\hline Gov_Net_Tone & & & $\begin{array}{l}0.0017 \\
(0.04)\end{array}$ \\
\hline Gov_Net_Tone*frc & & & $\begin{array}{l}-0.0561 \\
(-0.09)\end{array}$ \\
\hline Controls & YES & YES & YES \\
\hline Year FE & YES & YES & YES \\
\hline Firm FE & YES & YES & YES \\
\hline Industry FE & YES & YES & YES \\
\hline Observations & 2,322 & 2,322 & 2,322 \\
\hline VIF & 4.26 & 4.26 & 4.18 \\
\hline Adj-R2 & $78.59 \%$ & $78.59 \%$ & $78.43 \%$ \\
\hline
\end{tabular}

*Significance at the $10 \%$ level; **significance at the $5 \%$ level; *** significance at the $1 \%$ level. Coefficient for each variable is mentioned, t-test scores are between brackets

Following our main analyses, we run the same model to investigate FRC guidance moderation effects but using Exec_Net_Tone and Gov_Net_Tone instead of using just Net_ Tone for all annual reports. Column (2) in Table 7 shows that Exec_Net_Tone remains positively and significantly associated with future performance. In addition, the interaction between Exec_Net_Tone and FRC is positively and significantly associated with future performance, with a coefficient of 0.1698 and t value of 0.57 . However, column (3) in Table 7 shows that the interaction between Gov_Net_Tone and FRC is not significantly associated with Future performance. There results support our main analysis when we find executives' tone, but not governances' tone, has the power to predict future performance. Therefore, we conclude that the FRC narratives guidance improves the power of corporate tone in general and executives' tone in particular in predicting a company's future performance.

\subsubsection{Future market performance}

In our main analyses, we used future ROA as a proxy of future performance, focusing on accounting-based performance. However, in our additional analysis we aim to investigate if narrative tone can predict future market performance. Therefore, we use future Tobin's Q ratio as a proxy of future market-based performance. Table 8 shows that corporate net optimistic tone, executive net optimistic tone and governance net optimistic tone are positively associated with future market performance, however, they are not significant. These results 
Table 8 Narratives tone predictive power (future market performance)

\begin{tabular}{|c|c|c|c|}
\hline Tobin's Q+1 & Model (1) & Model (2) & Model (3) \\
\hline Intercept & $\begin{array}{l}0.3699 * * * \\
(3.28)\end{array}$ & $\begin{array}{l}0.2538 * * \\
(2.22)\end{array}$ & $\begin{array}{l}0.3832 * * * \\
(3.11)\end{array}$ \\
\hline Net_Tone & $\begin{array}{l}0.9754 \\
(1.15)\end{array}$ & & \\
\hline Exec_Net_Tone & & $\begin{array}{l}0.8245 \\
(1.27)\end{array}$ & \\
\hline Gov_Net_Tone & & & $\begin{array}{l}0.2891 \\
(0.54)\end{array}$ \\
\hline Size & $\begin{array}{l}-0.4553 * * * \\
(-4.32)\end{array}$ & $\begin{array}{l}-0.4562 * * * \\
(-4.33)\end{array}$ & $\begin{array}{l}-0.4411 \text { **** } \\
(-4.21)\end{array}$ \\
\hline Lev & $\begin{array}{l}-0.0035^{*} \\
(-1.15)\end{array}$ & $\begin{array}{l}-0.0035^{*} \\
(-1.14)\end{array}$ & $\begin{array}{l}-0.0037^{*} \\
(-1.22)\end{array}$ \\
\hline MTB & $\begin{array}{l}0.0159 * * * \\
(14.57)\end{array}$ & $\begin{array}{l}0.0159 * * * \\
(14.56)\end{array}$ & $\begin{array}{l}0.0159 * * * \\
(12.58)\end{array}$ \\
\hline DIV & $\begin{array}{l}0.3599^{* * *} \\
(1.63)\end{array}$ & $\begin{array}{l}0.3581 * * \\
(1.62)\end{array}$ & $\begin{array}{l}0.3716^{* *} \\
(1.68)\end{array}$ \\
\hline Cur_Tobin's Q & $\begin{array}{l}0.2017 * * * \\
(6.76)\end{array}$ & $\begin{array}{l}0.0202 * * * \\
(6.76)\end{array}$ & $\begin{array}{l}0.0202 * * * \\
(6.76)\end{array}$ \\
\hline S_Grwoth & $\begin{array}{l}0.0185^{* * *} \\
(1.96)\end{array}$ & $\begin{array}{l}0.0183 * * \\
(1.96)\end{array}$ & $\begin{array}{l}0.0192 * * \\
(2.10)\end{array}$ \\
\hline Year FE & YES & YES & YES \\
\hline Firm FE & YES & YES & YES \\
\hline Industry FE & YES & YES & YES \\
\hline Observations & 2,322 & 2,322 & 2,322 \\
\hline VIF & 4.09 & 4.09 & 3.06 \\
\hline Adj-R2 & $91.10 \%$ & $91.10 \%$ & $91.08 \%$ \\
\hline
\end{tabular}

*Significance at the $10 \%$ level; **significance at the $5 \%$ level; *** significance at the $1 \%$ level. Coefficient for each variable is mentioned, t-test scores are between brackets

are consistent with Wisniewski and Yekini (2015) when they found optimism in annual reports narratives is positive but not significant with future stock returns. In addition, our results are in line with prior studies that found positive tone is not significant with stock market reaction in the long term (Arslan-Ayaydin et al. 2016; Huang et al. 2014).

\section{Conclusion}

The current research aims to examine not only narrative tone predictive power but also who has this predictive power inside the company (executives or governance). It is expected that both groups will not have the same tone consistency in their narrative reporting as they have different responsibilities. Executives are responsible for providing a fair view about companies' performance and future strategies, whereas, governance is responsible for monitoring the internal quality controls and financial reporting process. The current study used Loughran and McDonald (2011) dictionary to conduct a computerized content analysis for the UK annual reports narratives, 2,437 observations, to measure NDT. Our findings show that corporate narrative tone can predict future performance, however, our 
main interest is to investigate who has this predictive power. We found that executive's tone has the power to predict companies' future performance but not governance tone.

We contribute to the debate on who has the power to predict future performance inside the company (executives vs. governance). Moreover, this study contributes to the accounting literature by providing an evidence about linguistic tone predictive power from the UK context that follows principles-based approach with more flexible financial reporting style and more opportunity for tone management. In addition, we highlight the importance of FRC narrative guidance in improving tone's predictive power and its ability to expect future performance. Therefore, our study has practical implications by showing investors and analysts the part of annual reports that might predict future performance. Moreover, it provides an evidence about the importance of narratives guidance issued by regulators.

This study is not free from limitations. First, while we use bag-of-words approach to capture tone, future research might develop an alternative method that focuses on meanings rather than word frequency. Second, our main focus was annual reports narratives in order to compare between executives and governance sections, however, future studies might compare between different documents of narrative reporting to investigate which channel affects market reaction and firms' outcomes more. Finally, based on our results, it is suggested for future research to investigate the characteristics of executives who provide higher positive tone in different contexts.

Data availability Data is available on online databases.

\section{Declarations}

Conflict of interest Authors declare that they have no conflict of interest.

Open Access This article is licensed under a Creative Commons Attribution 4.0 International License, which permits use, sharing, adaptation, distribution and reproduction in any medium or format, as long as you give appropriate credit to the original author(s) and the source, provide a link to the Creative Commons licence, and indicate if changes were made. The images or other third party material in this article are included in the article's Creative Commons licence, unless indicated otherwise in a credit line to the material. If material is not included in the article's Creative Commons licence and your intended use is not permitted by statutory regulation or exceeds the permitted use, you will need to obtain permission directly from the copyright holder. To view a copy of this licence, visit http://creativecommons.org/licenses/by/4.0/.

\section{References}

Arslan-Ayaydin Ö, Boudt K, Thewissen J (2016) Managers set the tone: equity incentives and the tone of earnings press releases. J Bank Financ 72:S132-S147. https://doi.org/10.1016/j.jbankfin.2015.10.007

Ataullah A, Vivian A, Xu B (2018) Optimistic disclosure tone and conservative debt policy. Abacus 54(4):445-484. https://doi.org/10.1111/abac.12140

Baginski SP, Demers E, Kausar A, Yu YJ (2018) Linguistic tone and the small trader. Acc Organ Soc 68:21-37. https://doi.org/10.1016/j.aos.2018.03.005

Barakat A, Ashby S, Fenn P, Bryce C (2019) Operational risk and reputation in financial institutions: does media tone make a difference? J Bank Financ 98:1-24. https://doi.org/10.1016/j.jbankfin.2018.10.007

Bartov E, Faurel L, Mohanram PS (2018) Can twitter help predict firm-level earnings and stock returns? Account Rev 93(3):25-57. https://doi.org/10.2308/accr-51865

Bassyouny H, Abdelfattah T, Tao L (2020) Beyond narrative disclosure tone: the upper echelons theory perspective. Int Rev Financ Anal. https://doi.org/10.1016/j.irfa.2020.101499 
Bhardwaj A, Imam S (2019) The tone and readability of the media during the financial crisis: evidence from pre-IPO media coverage. Int Rev Financ Anal 63:40-48. https://doi.org/10.1016/j.irfa.2019.02.001

Blankespoor E (2018) Firm communication and investor response: a framework and discussion integrating social media. Acc Organ Soc 68:80-87. https://doi.org/10.1016/j.aos.2018.03.009

Borochin PA, Cicon JE, DeLisle RJ, Price SM (2018) The effects of conference call tones on market perceptions of value uncertainty. J Financ Mark 40:75-91. https://doi.org/10.1016/j.finmar.2017.12.003

Boudt K, Thewissen J, Torsin W (2018) When does the tone of earnings press releases matter? Int Rev Financ Anal 57:231-245. https://doi.org/10.1016/j.irfa.2018.02.002

Brochet F, Miller GS, Naranjo P, Yu G (2019) Managers' cultural background and disclosure attributes. Account Rev 94(3):57-86. https://doi.org/10.2308/accr-52290

Bryan SH (1997) Incremental information content of required disclosures contained in management discussion and analysis. The Accounting Review 72(2):285-301. https://www.jstor.org/stable/248557

Chatterjee S, Price B (1991) Regression diagnostics. John Wiley, New York

Clatworthy MA, Jones MJ (2006) Differential patterns of textual characteristics and company performance in the chairman's statement. Account Audit Account J 19(4):493-511. https://doi.org/10.1108/09513 570610679100

Clatworthy M, Jones MJ (2003) Financial reporting of good news and bad news: evidence from accounting narratives. Account Bus Res 33(3):171-185. https://doi.org/10.1080/00014788.2003.9729645

D’Augusta C, DeAngelis MD (2020) Tone concavity around expected earnings. Account Rev 95(1):133164. https://doi.org/10.2308/accr-52448

Davis AK, Tama-Sweet I (2012) Managers' use of language across alternative disclosure outlets: earnings press releases versus MD\&A. Contemp Account Res 29(3):804-837. https://doi.org/10.1111/j.19113846.2011.01125.x

Davis AK, Ge W, Matsumoto D, Zhang JL (2015) The effect of manager-specific optimism on the tone of earnings conference calls. Rev Acc Stud 20(2):639-673. https://doi.org/10.1007/s11142-014-9309-4

Davis AK, Piger JM, Sedor LM (2012) Beyond the numbers: measuring the information content of earnings press release language. Contemp Account Res 29(3):845-868. https://doi.org/10.1111/j.1911-3846. 2011.01130.x

DeBoskey DG, Luo Y, Zhou L (2019) CEO power, board oversight, and earnings announcement tone. Rev Quant Financ Acc 52(2):657-680. https://doi.org/10.1007/s11156-018-0721-x

DeHaan E, Shevlin TJ, Thornock JR (2015) Market (in) attention and the strategic scheduling and timing of earnings announcements. J Account Econ 60(1):36-55. https://doi.org/10.1016/j.jacceco.2015.03.003

Dhaliwal DS, Li OZ, Tsang A, Yang YG (2011) Voluntary nonfinancial disclosure and the cost of equity capital: the initiation of corporate social responsibility reporting. Account Rev 86(1):59-100. https:// doi.org/10.2308/accr.00000005

Druz M, Petzev I, Wagner AF, Zeckhauser RJ (2020) When managers change their tone, analysts and investors change their tune. Financ Anal J 76(2):47-69. https://doi.org/10.1080/0015198X.2019.1707592

Du S, Yu K (2020) Do corporate social responsibility reports convey value relevant information? evidence from report readability and tone. J Bus Ethics. https://doi.org/10.1007/s10551-020-04496-3

El-Haj M, Alves P, Rayson P, Walker M, Young S (2020) Retrieving, classifying and analysing narrative commentary in unstructured (glossy) annual reports published as PDF files. Account Bus Res. https:// doi.org/10.1080/00014788.2019.1609346

Elshandidy T, Fraser I, Hussainey K (2015) What drives mandatory and voluntary risk reporting variations across Germany, UK and US? Br Account Rev 47(4):376-394. https://doi.org/10.1016/j.bar.2014.06. 001

Feldman R, Govindaraj S, Livnat J, Segal B (2010) Management's tone change, post earnings announcement drift and accruals. Rev Acc Stud 15(4):915-953. https://doi.org/10.1007/s11142-009-9111-X

FRC. (2014) Guidance on The Strategic Report. London, June.

Gordon EA, Henry E, Peytcheva M, Sun L (2013) Discretionary disclosure and the market reaction to restatements. Rev Quant Financ Acc 41(1):75-110. https://doi.org/10.1007/s11156-012-0301-4

Gray R, Kouhy R, Lavers S (1995) Corporate social and environmental reporting: a review of the literature and a longitudinal study of UK disclosure. Account Audit Account J 8(2):47-77. https://doi.org/10. $1108 / 09513579510146996$

Hassanein A, Zalata A, Hussainey K (2019) Do forward-looking narratives affect investors' valuation of UK FTSE all-shares firms? Rev Quant Financ Acc 52(2):493-519. https://doi.org/10.1007/ s11156-018-0717-6

Henry E (2008) Are investors influenced by how earnings press releases are written? J Bus Commun 45(4):363-407. https://doi.org/10.1177/0021943608319388 
Henry E, Leone AJ (2016) Measuring qualitative information in capital markets research: comparison of alternative methodologies to measure disclosure tone. Account Rev 91(1):153-178. https://doi.org/10. 2308/accr-51161

Huang X, Teoh SH, Zhang Y (2014) Tone management. Account Rev 89(3):1083-1113. https://doi.org/10. 2308/accr-50684

Hussainey K, Schleicher T, Walker M (2003) Undertaking large-scale disclosure studies when AIMR-FAF ratings are not available: the case of prices leading earnings. Account Bus Res 33(4):275-294. https:// doi.org/10.1080/00014788.2003.9729654

Hussein M, Zhou ZG, Deng Q (2020) Does risk disclosure in prospectus matter in ChiNext IPOs' initial underpricing? Rev Quant Financ Acc. https://doi.org/10.1007/s11156-019-00812-9

Iatridis GE (2016) Financial reporting language in financial statements: does pessimism restrict the potential for managerial opportunism? Int Rev Financ Anal 45:1-17. https://doi.org/10.1016/j.irfa.2016.02.004

Kimbrough MD, Wang IY (2013) Are seemingly self-serving attributions in earnings press releases plausible? empirical evidence. Account Rev 89(2):635-667. https://doi.org/10.2308/accr-50628

Kothari SP, Li X, Short JE (2009) The effect of disclosures by management, analysts, and business press on cost of capital, return volatility, and analyst forecasts: a study using content analysis. Account Rev 84(5):1639-1670. https://doi.org/10.2308/accr.2009.84.5.1639

Lee J, Park J (2019) The impact of audit committee financial expertise on management discussion and analysis (MD\&A) tone. Eur Account Rev 28(1):129-150. https://doi.org/10.1080/09638180.2018.1447387

Li F (2010) The information content of forward-looking statements in corporate filings-a naïve Bayesian machine learning approach. J Account Res 48(5):1049-1102. https://doi.org/10.1111/j.1475-679X. 2010.00382.x

Linsley PM, Shrives PJ (2006) Risk reporting: a study of risk disclosures in the annual reports of UK companies. Br Account Rev 38(4):387-404. https://doi.org/10.1016/j.bar.2006.05.002

Loughran T, McDonald B (2011) When is a liability not a liability? textual analysis, dictionaries, and 10-Ks. J Financ 66(1):35-65. https://doi.org/10.1111/j.1540-6261.2010.01625.x

Loughran T, McDonald B (2016) Textual analysis in accounting and finance: a survey. J Account Res 54(4):1187-1230. https://doi.org/10.1111/1475-679X.12123

Mangena M, Pike R (2005) The effect of audit committee shareholding, financial expertise and size on interim financial disclosures. Account Bus Res 35(4):327-349

Marquez-Illescas G, Zebedee AA, Zhou L (2019) Hear me write: does CEO narcissism Affect disclosure? J Bus Ethics. https://doi.org/10.1007/s10551-018-3796-3

Melloni G, Stacchezzini R, Lai A (2016) The tone of business model disclosure: an impression management analysis of the integrated reports. J Manag Gov 20(2):295-320. https://doi.org/10.1007/ s10997-015-9319-z

Merkley KJ (2014) Narrative disclosure and earnings performance: evidence from R\&D disclosures. Account Rev 89(2):725-757. https://doi.org/10.2308/accr-50649

Patelli L, Pedrini M (2014) Is the optimism in CEO's letters to shareholders sincere? impression management versus communicative action during the economic crisis. J Bus Ethics 124(1):19-34. https://doi. org/10.1007/s10551-013-1855-3

Pennebaker JW, Mehl MR, Niederhoffer KG (2003) Psychological aspects of natural language use: our words, our selves. Ann Rev Psychol 54(1):547-577. https://doi.org/10.1146/annurev.psych.54.101601. 145041

Price SM, Doran JS, Peterson DR, Bliss BA (2012) Earnings conference calls and stock returns: the incremental informativeness of textual tone. J Bank Finance 36(4):992-1011. https://doi.org/10.1016/j. jbankfin.2011.10.013

Rahman S (2019) Discretionary tone, annual earnings and market returns: evidence from UK interim management statements. Int Rev Financ Anal. https://doi.org/10.1016/j.irfa.2019.101384

Rogers JL, Van Buskirk A, Zechman SL (2011) Disclosure tone and shareholder litigation. Account Rev 86(6):2155-2183. https://doi.org/10.2308/accr-10137

Schleicher T, Walker M (2010) Bias in the tone of forward-looking narratives. Account Bus Res 40(4):371390. https://doi.org/10.1080/00014788.2010.9995318

Smith M, Taffler RJ (2000) The chairman's statement-a content analysis of discretionary narrative disclosures. Account Audit Account J 13(5):624-647. https://doi.org/10.1108/09513570010353738

Spence M (1973) Competitive and optimal responses to signals: an analysis of efficiency and distribution. J Econ Theory 7(3):296-332

Sprenger TO, Sandner PG, Tumasjan A, Welpe IM (2014) News or noise? using twitter to identify and understand company-specific news flow. J Bus Financ Acc 41(7-8):791-830. https://doi.org/10.1111/ jbfa. 12086 
Tan HT, Ying Wang E, Zhou BO (2014) When the use of positive language backfires: the joint effect of tone, readability, and investor sophistication on earnings judgments. J Account Res 52(1):273-302. https://doi.org/10.1111/1475-679X.12039

Tetlock PC (2007) Giving content to investor sentiment: the role of media in the stock market. J Financ 62(3):1139-1168. https://doi.org/10.1111/j.1540-6261.2007.01232.x

Tetlock PC, Saar-Tsechansky M, Macskassy S (2008) More than words: quantifying language to measure firms' fundamentals. J Financ 63(3):1437-1467

Wang M, Hussainey K (2013) Voluntary forward-looking statements driven by corporate governance and their value relevance. J Account Public Policy 32(3):26-49. https://doi.org/10.1016/j.jaccpubpol.2013. 02.009

Wisniewski TP, Yekini LS (2015) Stock market returns and the content of annual report narratives. Accounting Forum 39(4):281-294. https://doi.org/10.1016/j.accfor.2015.09.001

Yekini LS, Wisniewski TP, Millo Y (2016) Market reaction to the positiveness of annual report narratives. Br Account Rev 48(4):415-430. https://doi.org/10.1016/j.bar.2015.12.001

Zalata AM, Tauringana V, Tingbani I (2018) Audit committee financial expertise, gender, and earnings management: does gender of the financial expert matter? Int Rev Financ Anal 55:170-183. https://doi. org/10.1016/j.irfa.2017.11.002

Publisher's Note Springer Nature remains neutral with regard to jurisdictional claims in published maps and institutional affiliations. 